\title{
Mineralogical Characterization of Carreaux de Pavement from Northern Spain (Tiebas, Navarre)
}

\author{
Iván Ruiz-Ardanaz, Esther Lasheras (D) and Adrián Durán * \\ Chemistry Department, University of Navarre, Irunlarrea 1, 31008 Pamplona, Spain; \\ iruiz.23@alumni.unav.es (I.R.-A.); elasheras@unav.es (E.L.) \\ * Correspondence: adrianduran@unav.es
}

check for updates

Citation: Ruiz-Ardanaz, I.;

Lasheras, E.; Durán, A. Mineralogical Characterization of Carreaux de Pavement from Northern Spain (Tiebas, Navarre). Minerals 2021, 11, 153. https://doi.org/ $10.3390 / \min 11020153$

Academic Editors: Petrus J Le Roux and Davide Lenaz

Received: 28 December 2020

Accepted: 28 January 2021

Published: 1 February 2021

Publisher's Note: MDPI stays neutral with regard to jurisdictional claims in published maps and institutional affiliations.

Copyright: (C) 2021 by the authors. Licensee MDPI, Basel, Switzerland. This article is an open access article distributed under the terms and conditions of the Creative Commons Attribution (CC BY) license (https:// creativecommons.org/licenses/by/ $4.0 /)$.

\begin{abstract}
Several medieval tiles from Tiebas Castle in Navarre, classified as carreaux de pavement, were mineralogically analyzed. The aim was to add information to the very scarce analytical data available for carreaux de pavement in order to provide a quality primary work, mainly descriptive, in this topic. The characterization techniques applied were: optical microscopy (OM), colorimetry, Fourier transform infrared (FT-IR) spectroscopy, differential thermal analysis and thermogravimetry (DTA-TG), X-ray fluorescence (XRF) spectroscopy, petrographic microscopy (PM), X-ray diffraction (XRD), scanning electron microscopy coupled with energy dispersive X-ray spectroscopy (SEM-EDS). The tiles comprised three layers: a top glaze with mainly silicon and lead-based compounds; a thin layer of silicoaluminate (very possibly kaolinite) called engobe under it; and the pastes, composed of quartz, hematite, potassium feldspars and calcite. Honey glazes were richer in iron, being copperbased compounds responsible for dark green glazes. The orangish-reddish color of the pastes was provided by hematite. Although the tiles were found in three different locations within the castle, no significant differences were detected among them. The carreaux de pavement from Tiebas had similarities with that from the Bordeaux region. According to the composition data and thickness of tiles from other French carreaux de pavement, the Tiebas artifacts were dated to the 13th century.
\end{abstract}

Keywords: carreaux de pavement; medieval pottery; archaeometry; mineralogical analysis; plumbiferous glaze; silicoaluminate engobe; reddish paste

\section{Introduction}

Carreaux de pavement is the French name given to a medieval type of glazed pottery, which has been referred to in several publications as inlaid tiles, encaustic tiles, carreaux de pavage, or carrelages de sol [1]. The most frequent are carreaux de pavement in the French lexicon and encaustic tiles in the English one [2]. This type of pottery is characterized by its inlaid decoration and three layers: the outer one is usually a very thin glaze with different color tones; another thin layer of paste under it that is called engobe, which fills gaps in the inner and thicker layer, named paste; and paste, which is normally reddish [1,2].

Carreaux de pavement appeared in Great Britain and northern France in the mid-12th century as an evolution of glazed monochromatic tiles used to luxuriously cover the floors of nobility and royal buildings (castles, palaces, cathedrals, churches, chapels, abbeys, monastic houses ... ) [1-3]. An important role has been attributed to Cistercian monks in developing techniques for making terracotta, and more particularly, monochromatic tiles for paving their churches [2,3]. Monochromatic tiles led to dichromatic tiles at the beginning of the 13th century [1,2]. In the second half of the 13th century and especially in the 14th century, the expansion and use of these tiles increased, being set in a multitude of palaces, monasteries, abbeys, and churches, and also extended geographically to the south of France, Ireland, Belgium, and western Germany [1,2]. At the end of this period, the lead glaze began to be replaced by tin glaze. The tin glaze was extended mainly during the 15 th century [2]. In the first half of the 19th century, the rise of English Neo-Gothic revived the production of carreaux de pavement, erroneously called encaustic tiles [1,2]. 
Tiebas Castle, located in Navarre (northern Spain) (Figure 1a), is the only place in the Iberian Peninsula where this type of tile has been found [4]. Due to their chronology and decoration, they were not related to the workshops of Bordeaux and Toulouse, but rather to the Champagne region $[5,6]$. The reason why these tiles appeared so far south was probably because the kingdom of Navarre was being ruled by the kings of the Champagne dynasty from 1234 to 1274 [7,8]. Theobald II of Navarre (1254-1270), the second king, ordered the construction of the castle of Tiebas at the beginning of his reign according to the stylistic models of that time [4,9-11].


Figure 1. (a) Location of Tiebas Castle in Navarre (northern Spain). (b) Modified early 19th century map of the Tiebas Castle with the locations of where the tiles were found: in situ Northern Hall (blue area), landfill (orange area), out-of-context fragments (green area).

The tiles analyzed in this work were recently found during an archaeological intervention. A pavement consisting of thousands of tiles with decorative motifs appeared in situ in the Northern Hall of Tiebas Castle (Figure 1b). These were dated to around 1256 thanks to the fact that they were covered by a layer of ash and rubble that was attributed to the fire of 1378 as well as their style and decorative motifs [4]. Similar tiles had already been found in previous archaeological surveys [9-11] such as those in the excavation of the Hermitage of Santa Catalina (ancient chapel close to Tiebas Castle). In this other location, fragments and complete tiles were found in a close landfill (Figure 1b) [11]. Other fragments also appeared out of the archaeological context on the slopes of the Castle hill (Figure 1b), which were not completely buried and were exposed to environmental agents and pollution $[9,10]$. The fragments and complete tiles ex situ were surely originally in the Northern Hall, but had been withdrawn and discarded at some later time [11].

Some studies have been performed on medieval artifacts of carreaux de pavement, mainly using scanning electron microscopy coupled to an energy dispersive X-ray detector (SEM-EDS) [5,6,12-14], inductively coupled plasma atomic emission spectroscopy (ICPAES) [15], X-ray diffraction (XRD) [12], cathodoluminescence [12], differential thermal analysis-thermogravimetry analysis (DTA-TGA) [12], or petrographic microscopy (PM) [13]. These studies, although scarce, can be useful as references since they chemically analyzed samples of medieval carreaux de pavement (mainly dated to 13th and 14th centuries) from different zones of French geography. Some of these publications even made it possible to differentiate between materials from the 13th and 14th centuries. The coincidence 
in typology (carreaux de pavement) [4], the geographical proximity, the linked historical context $[7,8]$, and the dating within the same period [4] allowed the results of these studies to be compared with those obtained in this article. According to the information provided by these articles, the pastes could be classified in two types depending on the calcium oxide content: one pinkish or orangish with moderate percentage of $\mathrm{CaO}$ (mean values ca. $20 \%$ ), and the other of reddish color and with a very low quantity of $\mathrm{CaO}(0.4-1.5 \%)[5,6,12,13,15]$. The composition of the engobe layers was based on clay minerals or lime $[5,6,12,14]$. The glazes could also be classified depending on their light transmittance, so occurring opaque glazes were formed by a mixture of $\mathrm{PbO}, \mathrm{SnO}$, and clays, and transparent glazes with $\mathrm{PbO}$ and clays [5,6,12-14]. Metreau L et al. [13] classified the tiles found in Sarzeau in Northern France according to their thickness and the dates in which the tiles were made.

The investigation is mainly descriptive in nature with the main objective of adding information to the very scarce analytical data available for carreaux de pavement. In this sense, thanks to this study, the elemental and mineral compositions of the tiles from Tiebas Castle were determined as well as the possible differences between the tiles found in the different locations within the Castle and also with French production. The work will shed light on the raw materials used. The work presented did not aim to mainly address fundamental unsolved issues on the topic, but to provide meaningful, quality primary work to aid future workers in such efforts.

\section{Materials and Methods}

\subsection{Materials}

Around 7000-7500 tiles were installed in Tiebas Castle, most of them consisting of quadrangular tiles around $13-15 \mathrm{~cm}$ long, $13-15 \mathrm{~cm}$ wide, and $2-3 \mathrm{~cm}$ of thick; $62 \%$ of them were dichromatic and $38 \%$ were monochromatic [4,9]. Fragments of 22 tiles from carreaux de pavement were used in this research, most of them provided by the Registry, Movable, and Archeology Section of the Navarre Government. The samples were selected and classified (Figure 2, Table 1) according to the acceptable state of conservation of their three layers (paste, engobe, and glaze), type of decoration (monochromatic and dichromatic), and the archaeological location (Northern Hall, landfill, and out-of-context) (Figure 1b).



Figure 2. Analyzed tile fragments of carreaux de pavement from Tiebas Castle, classified by the type of decoration and archaeological location. 
Table 1. Description of tile samples studied and the analytical techniques applied on each one. Abbreviations: e-engobe; g-glaze; p-paste; M-monochromatic tile; D—dichromatic tile; NH-Northern Hall fragment; LF-landfill fragment; OOC—out of context fragment; LHon—light honey glaze; DGre—dark green glaze; LGre—light green glaze.

\begin{tabular}{|c|c|c|c|c|c|c|c|c|c|c|c|c|}
\hline \multirow{2}{*}{ Code } & \multirow[t]{2}{*}{ Type } & \multirow{2}{*}{ Site } & \multirow{2}{*}{$\begin{array}{l}\text { Glaze } \\
\text { (color) }\end{array}$} & \multirow{2}{*}{$\begin{array}{l}\text { Thickness } \\
(\mathrm{mm})\end{array}$} & \multirow{2}{*}{$\begin{array}{c}\text { Colorimetry } \\
\text { p g e }\end{array}$} & \multirow{2}{*}{$\begin{array}{c}\text { FTIR } \\
p \\
\end{array}$} & \multirow{2}{*}{$\begin{array}{c}\text { DTA/TG } \\
p\end{array}$} & \multirow{2}{*}{$\begin{array}{l}\text { XRD } \\
\text { pge }\end{array}$} & \multirow{2}{*}{$\begin{array}{l}\text { XRF } \\
\text { pge }\end{array}$} & \multirow{2}{*}{$\frac{\mathrm{OM}}{\mathrm{a}}$} & \multirow{2}{*}{$\begin{array}{c}\mathrm{PM} \\
\mathrm{p}\end{array}$} & \multirow{2}{*}{$\begin{array}{c}\text { SEM/ } \\
\text { EDS } \\
\mathbf{a} \\
\end{array}$} \\
\hline & & & & & & & & & & & & \\
\hline M1 & M & $\mathrm{NH}$ & DGre & 23.6 & $\checkmark \checkmark-$ & $\checkmark$ & $\checkmark$ & $\checkmark \checkmark-$ & $\checkmark \checkmark-$ & $\checkmark$ & - & - \\
\hline M3 & M & $\mathrm{NH}$ & DGre & 23.8 & $\checkmark \checkmark-$ & $\checkmark$ & $\checkmark$ & $\checkmark-$ & $\checkmark-$ & $\checkmark$ & - & - \\
\hline M5 & M & $\mathrm{NH}$ & DGre & 25.7 & $\sqrt{ }-$ & $\checkmark$ & $\checkmark$ & $\checkmark \checkmark-$ & $\checkmark-$ & $\checkmark$ & - & - \\
\hline M8 & M & LF & DGre & 24.5 & $\sqrt{ }-$ & $\checkmark$ & $\checkmark$ & $\checkmark-$ & $\checkmark-$ & $\checkmark$ & - & - \\
\hline M9 & M & $\mathrm{LF}$ & DGre & 23.2 & $\checkmark \checkmark-$ & $\checkmark$ & $\checkmark$ & $\checkmark-$ & $\checkmark-$ & $\checkmark$ & - & - \\
\hline M10 & M & LF & DGre & 25.3 & $\sqrt{ }-$ & $\checkmark$ & $\checkmark$ & $\checkmark \checkmark-$ & $\checkmark \checkmark-$ & $\checkmark$ & - & $\checkmark$ \\
\hline M1-15 & M & OOC & - & 23.4 & $\checkmark--$ & $\checkmark$ & $\checkmark$ & $\checkmark--$ & $\checkmark-$ & $\checkmark$ & - & - \\
\hline M1-50 & M & OOC & DGre & 22.4 & $\sqrt{ }-$ & $\checkmark$ & $\checkmark$ & $\checkmark-$ & $\checkmark-$ & $\checkmark$ & - & - \\
\hline M1-9 & M & OOC & LHon & 20.8 & $\sqrt{ }-$ & $\checkmark$ & $\checkmark$ & $\checkmark-$ & $\checkmark-$ & $\checkmark$ & - & - \\
\hline M6 & $\mathrm{D}$ & $\mathrm{NH}$ & DGre & 25.7 & $\checkmark \checkmark \checkmark$ & $\checkmark$ & $\checkmark$ & $\checkmark \checkmark-$ & $\checkmark \checkmark-$ & $\checkmark$ & - & $\checkmark$ \\
\hline M23 & $\mathrm{D}$ & $\mathrm{NH}$ & DGre & 28.3 & $\checkmark \checkmark \checkmark$ & $\checkmark$ & $\checkmark$ & $\sqrt{ }-$ & $\checkmark \checkmark-$ & $\checkmark$ & - & - \\
\hline M4 & $\mathrm{D}$ & $\mathrm{NH}$ & DGre & 24.9 & $\checkmark \checkmark \checkmark$ & $\checkmark$ & $\checkmark$ & $\checkmark$ & $\sqrt{ }-$ & $\checkmark$ & - & - \\
\hline M13 & $\mathrm{D}$ & LF & LHon & 24.8 & $\checkmark \checkmark \checkmark$ & $\checkmark$ & $\checkmark$ & $\checkmark-\checkmark$ & $\checkmark-\checkmark$ & $\checkmark$ & - & - \\
\hline M19 & $\mathrm{D}$ & $\mathrm{LF}$ & LGre & 23.6 & $\checkmark \checkmark \checkmark$ & $\checkmark$ & $\checkmark$ & $\checkmark \checkmark-$ & $\checkmark \checkmark-$ & $\checkmark$ & - & $\checkmark$ \\
\hline M20 & $\mathrm{D}$ & LF & LGre & 24.1 & $\checkmark \checkmark \checkmark$ & $\checkmark$ & $\checkmark$ & $\checkmark-$ & $\checkmark-$ & $\checkmark$ & - & - \\
\hline M21 & $\mathrm{D}$ & OOC & LHon & 25.2 & $\checkmark \checkmark \checkmark$ & $\checkmark$ & $\checkmark$ & $\checkmark \checkmark-$ & $\checkmark \checkmark-$ & $\checkmark$ & - & $\checkmark$ \\
\hline M22 & $\mathrm{D}$ & OOC & LHon & 24.4 & $\checkmark \checkmark \checkmark$ & $\checkmark$ & $\checkmark$ & $\checkmark \checkmark-$ & $\checkmark \checkmark-$ & $\checkmark$ & - & $\checkmark$ \\
\hline M1-21 & $\mathrm{D}$ & OOC & LHon & 25.4 & $\checkmark \checkmark \checkmark$ & $\checkmark$ & $\checkmark$ & $\checkmark \checkmark-$ & $\checkmark-$ & $\checkmark$ & - & - \\
\hline M32 & $\mathrm{D}$ & LF & LHon & 22.8 & $-\checkmark-$ & - & - & $-\checkmark-$ & $-\sqrt{-}$ & - & - & - \\
\hline M33 & $\mathrm{D}$ & LF & LHon & 22.2 & - - - & - & - & $--\checkmark$ & $--\checkmark$ & - & - & - \\
\hline M1-51 & - & OOC & - & - & - - - & - & - & - - - & - - - & - & $\checkmark$ & - \\
\hline M1-52 & - & OOC & - & - & - - - & - & - & - - - & - - & - & $\checkmark$ & - \\
\hline
\end{tabular}

Two types of monochromatic tiles were recognized, some of them with a dark greenish glaze and others with a honey glaze. Honey, light green, or dark green glazes can be seen in the dichromatic tiles, covering a whitish decoration that fills the gaps of the pastes (Table 1).

\subsection{Methods}

For optical microscopy (OM) and SEM-EDS, small tile samples were cut vertically. The samples were laid in a mold of polymethyl methacrylate, which was filled with a resin. One of the faces of the samples was polished, in this form, cross-sections with the three layers (glaze, engobe and paste) were obtained. Optical PCE-MM200 and electronic Hitachi S4800 microscopes were employed for the investigation.

For the colorimetric analyses, a Konica Minolta CM-2300d spectrophotometer with D65 light was used. The measurements were carried out in triplicate directly on the surface of the tiles. Values of the $\mathrm{L}^{*}, \mathrm{a}^{*}$, and $\mathrm{b}^{*}$ coordinates were measured. $\mathrm{L}^{*}$ represents lightness (100) to darkness (0); $\mathrm{a}^{*}$ gives information about reddish (positive $\mathrm{a}^{*}$ values) or greenish (negative $a^{*}$ values) colors; and $b^{*}$ about yellowish (positive $b^{*}$ ) or bluish (negative $b^{*}$ ).

To obtain the infrared spectra of the powder samples (after detaching the three different layers), a Shimadzu IRAffinity-1S spectrophotometer with a Golden Gate attenuated total reflectance (FTIR-ATR) accessory was employed (diamond-based ATR crystal with incidence angle of $45^{\circ}$ ). The acquisition was in the wavelength range between 600 and $4000 \mathrm{~cm}^{-1}$ with a resolution of $4 \mathrm{~cm}^{-1}$ and 100 scans/sample.

A simultaneous TG-sDTA 851 Mettler Toledo apparatus was used for thermal analyses (DTA-TG) by heating the powder samples from ambient temperature to $1000{ }^{\circ} \mathrm{C}$ in an alumina crucible under a $10^{\circ} \mathrm{C} / \mathrm{min}$ heating rate and static air atmosphere.

For the analyses by XRD and X-ray fluorescence spectroscopy (XRF), the paste samples were crushed in an agate mortar. In the case of the engobes and glazes, laminar samples $1-4 \mathrm{~cm}^{2}$ and $3 \mathrm{~mm}$ thick were prepared and measured in a non-destructive form. A Bruker S2 Puma instrument with a silver anode and helium atmosphere was used for the XRF analyses. The physical principle of acquisition was dispersion energy resource. A standard sample was measured before analyses to properly calibrate the energies' values. 
For the mineralogical determination, PM and XRD were employed. For PM, a Zeiss polarizing petrographic microscope was used in two of the paste samples. For XRD, a Bruker D8 Advance diffractometer with $\mathrm{Cu} \mathrm{K} \alpha$ radiation was used and an LYNXEYE XE-T detector. The experimental conditions for XRD experiments were: $2 \theta$ range from $5^{\circ}$ to $70^{\circ}$, $2 \mathrm{~s}$ per step, and step size of $0.02^{\circ}$.

An EDS Bruker-X Flash-4010 analyzer coupled to a SEM microscope was used for elemental punctual analyses and mappings performed on some of the cross-sections. For the SEM-EDS analysis, the samples were previously metallized with gold.

All experiments performed on the 22 selected tiles are depicted in Table 1.

\section{Results}

\subsection{Naked-Eye Observation and Optical Microscopy (OM)}

Some relevant macroscopic details were detected by looking properly at the tile pastes with the naked eye. Most tiles had a homogeneous paste, with no impurities or degreasers. Only in a few tiles were inclusions of small sandstone pebbles of diameters ca. 0.2-1 cm (M19, M1-15, M1-51), very tiny metal fragments of 0.5-3 mm (M1-51, M19), and air bubbles and cracks with diameters ca. $0.2-2 \mathrm{~cm}$ (M3, M21) filled with a yellowish powder (Figure $3 a, b$ ) detected. These irregularities were probably included during the production or molding of the clay. The pastes of two tiles, M19 and M20, showed an upper grey area and a lower reddish with an intermediate zone of mixed tones (Figure 4).
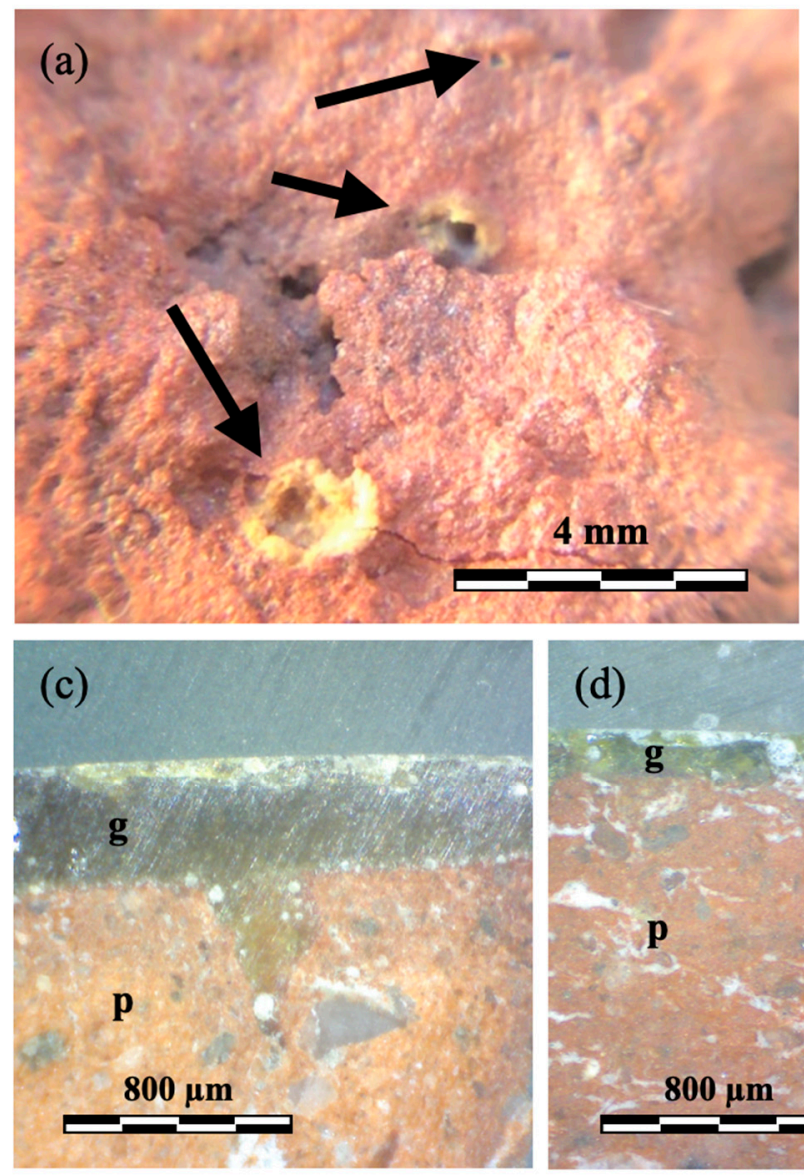
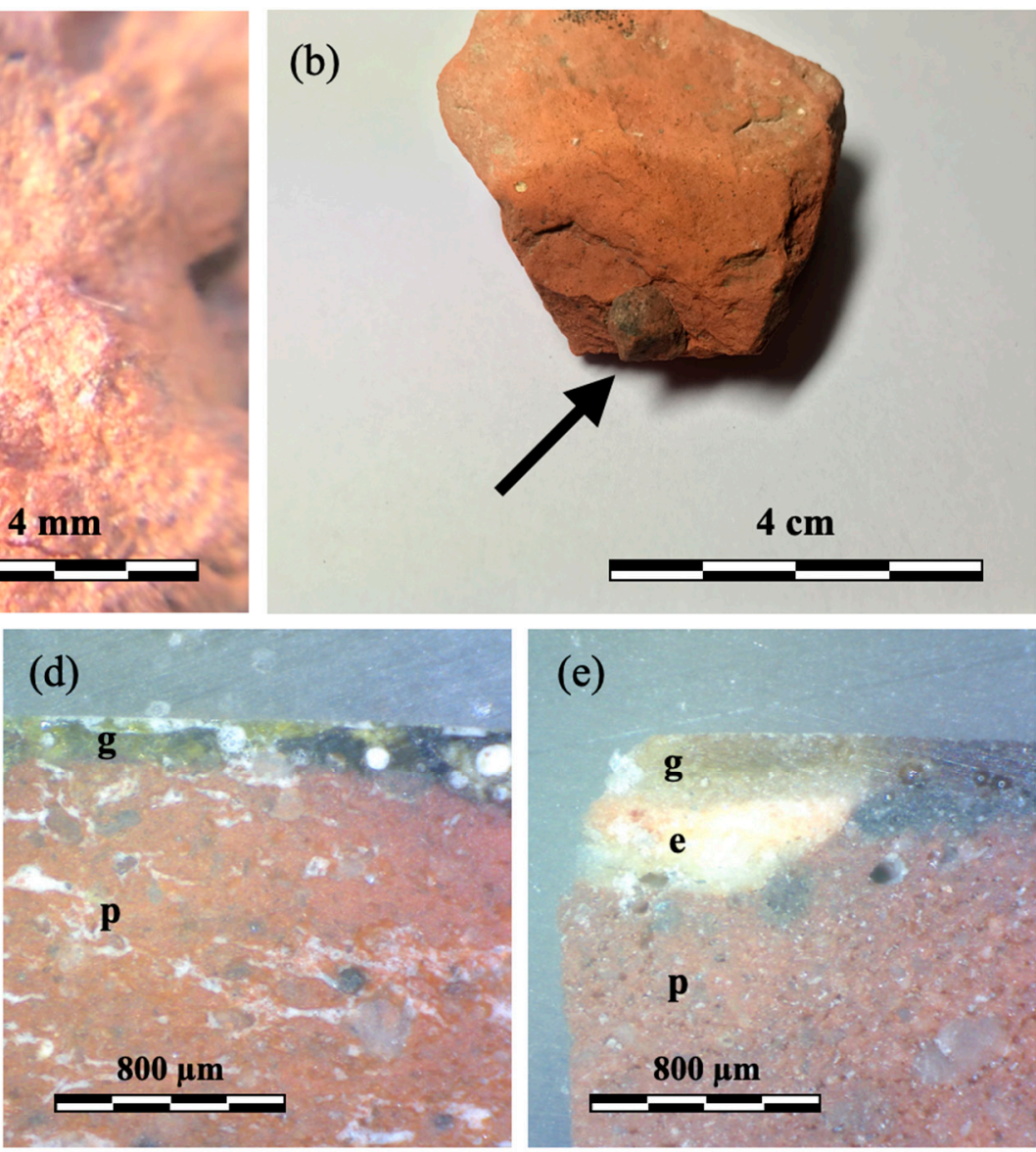

Figure 3. Images obtained by optical microscope $(40 \times, 200 \times)$ of the paste surface of the samples: (a) M21, and (b) M1-15. The arrows indicated air bubbles and sandstone pebble; and cross-sections of samples: (c) M22, (d) M8, and (e) M6. Abbreviations: $\mathrm{p}$-paste; e-engobe; g-glaze. 

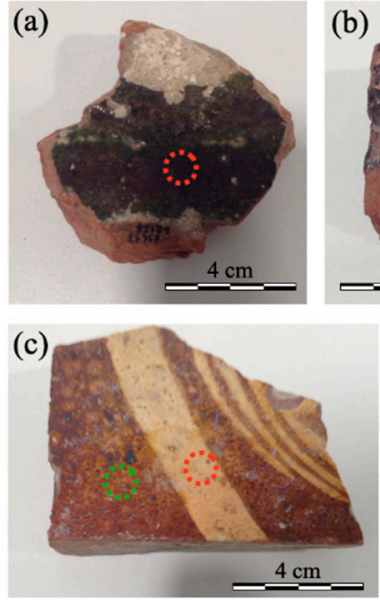

(b)

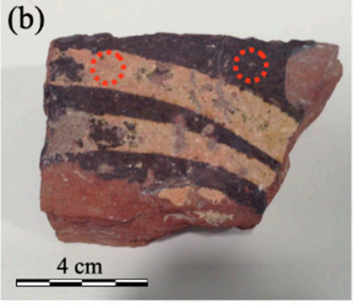

(d)

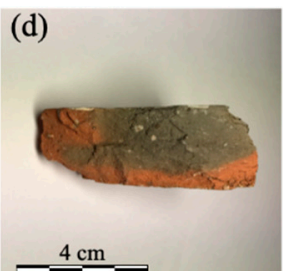

(e) ${ }^{20}$

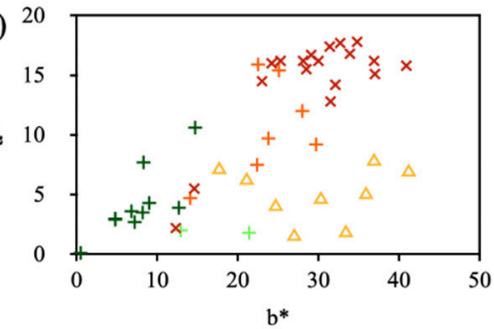

Paste

Engobe

+ Honey Glaze

+ Dark Glaze

Light green Glaze

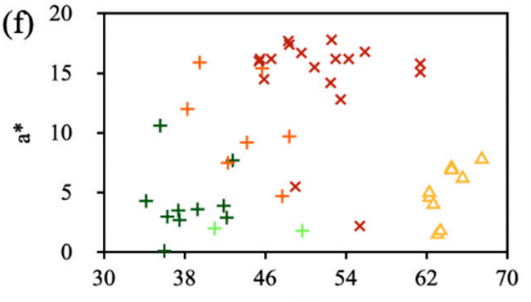

(g)

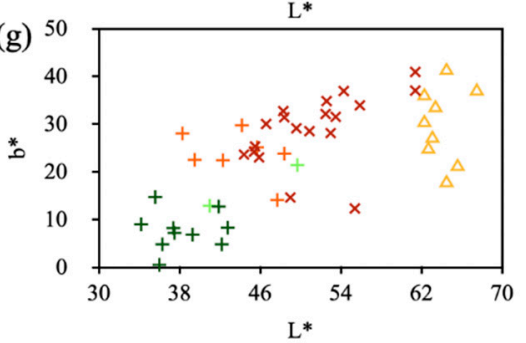

Figure 4. (a-d) Zones in which the colorimetric experiments were done in some of the samples studied: M10, M23, M22 and M19. (e-g) Colorimetric study of the different layers of the fragments.

The observation of the cross-sections by means of an optical microscope allowed us to understand the morphology and thickness of the two thinnest layers, the glaze and engobe (Figure $3 c, d$ ). The glazes had thicknesses ranging from $500 \mu \mathrm{m}$ to $100 \mu \mathrm{m}$ (Figure $3 \mathrm{c}, \mathrm{d}$ ), and from $900 \mu \mathrm{m}$ to $300 \mu \mathrm{m}$ in the engobes (Figure 3e). Small air bubbles in the glazes had thicknesses of ca. $50 \mu \mathrm{m}$ (Figure 3c,d). The pastes were composed of a very fine reddish matrix that had a particle size of less than $50 \mu \mathrm{m}$. In addition, crystals of light grey color (very possibly quartz) with an irregular shape and sizes ranging from 50 to $800 \mu \mathrm{m}$ were also observed (Figure 3c-e).

\subsection{Colorimetry}

A colorimetric analysis was carried in order to provide numerical values of the color variables $\left(L^{*}, a^{*}\right.$, and $\left.b^{*}\right)$. These values were used to compare the different layers within the fragment and the different fragments to each other. The results found in this investigation will be available for future comparisons with other carreaux de pavement.

The color of the tile pastes and glazes is closely related to both their elemental composition and mineralogy [16]. One of the main characteristic properties of carreaux de pavement is the intense reddish color of its paste [4,15]. The red color of the pastes are usually related to either a high iron (III) oxide content, an oxidizing atmosphere during firing, or both [16-19]. The presence of carbonate based-compounds could lighten the pastes, and organic matter, carbon, or moisture darken them [16,17].

As an example, Figure $4 \mathrm{a}-\mathrm{d}$ show some of the tile fragments in which different color measurements were carried out. In the sample M10, the measurements were performed on the dark greenish glaze (Figure 4a) and also on the paste; on the dark greenish glaze and whitish engobe in sample M23 (Figure 4b) and also in the paste; on the honey glaze and whitish engobe in sample M22 (Figure 4c) and also in the paste; and on the reddish and grey areas of the paste in sample M19 (Figure 4d).

Regarding the pastes, positive values of $\mathrm{a}^{*}$ and $\mathrm{b}^{*}$ were registered, ranging from 14 to 23 for $\mathrm{a}^{*}$ and from 23 to 41 for $\mathrm{b}^{*}$. These values are characteristic of reddish-orangish tones. $\mathrm{L}^{*}$ values oscillated between 44 and 62. In two of the studied tiles, M19 and M20, grey areas were present in the pastes (Figure 4d) as mentioned before, and consequently, the values of the $a^{*}$ and $b^{*}$ parameters were significantly reduced, especially for the pastes in sample M19 (Figure 4e-g and Table 2). 
Table 2. Chromaticity values of each tile sample and layer. Each piece of data is the arithmetic mean of three experiments.

\begin{tabular}{ccccccccccc}
\hline \multirow{2}{*}{ Sample } & Glaze & \multicolumn{3}{c}{ Paste } & \multicolumn{3}{c}{ Glaze } & \multicolumn{3}{c}{ Engobe } \\
\cline { 3 - 11 } & (Color) & $\mathbf{L}^{*}$ & $\mathbf{a}^{*}$ & $\mathbf{b}^{*}$ & $\mathbf{L}^{*}$ & $\mathbf{a}^{*}$ & $\mathbf{b}^{*}$ & $\mathbf{L}^{*}$ & $\mathbf{a}^{*}$ & $\mathbf{b}^{*}$ \\
\hline M1 & DGre & 44.4 & 22.8 & 23.6 & 39.3 & 3.6 & 6.8 & - & - & - \\
M3 & DGre & 45.5 & 16.2 & 25.3 & 42.2 & 2.9 & 4.8 & - & - & - \\
M4 & DGre & 49.6 & 16.7 & 29.1 & 42.8 & 7.7 & 8.3 & 64.5 & 7.1 & 17.7 \\
M5 & DGre & 53 & 16.2 & 28.1 & 35.6 & 10.6 & 14.7 & - & - & - \\
M6 & DGre & 45.4 & 16 & 24.2 & 37.5 & 2.7 & 7.2 & 65.6 & 6.2 & 21.1 \\
M8 & DGre & 48.3 & 17.7 & 32.7 & 37.4 & 3.5 & 8.2 & - & - & - \\
M9 & DGre & 48.4 & 17.4 & 31.4 & 36.3 & 3 & 4.8 & - & - & - \\
M10 & DGre & 50.9 & 15.5 & 28.5 & 41.9 & 3.9 & 12.7 & - & - & - \\
M23 & DGre & 45.9 & 14.5 & 23 & 34.2 & 4.3 & 9 & 62.7 & 4 & 24.7 \\
M1-50 & DGre & 53.5 & 12.8 & 31.5 & 36.1 & 0.1 & 0.5 & - & - & - \\
M19r & LGre & 61.4 & 15.1 & 37 & 49.7 & 1.8 & 21.4 & 63.1 & 1.5 & 27 \\
M19g & LGre & 55.4 & 2.2 & 12.3 & - & - & - & - & - & - \\
M20 & LGre & 49 & 5.5 & 14.6 & 41 & 2 & 12.9 & 63.4 & 1.8 & 33.4 \\
M13 & LHon & 52.5 & 14.2 & 32.1 & 47.7 & 4.7 & 14.1 & 62.3 & 4.6 & 30.3 \\
M21 & LHon & 52.6 & 17.8 & 34.8 & 48.4 & 9.7 & 23.8 & 67.5 & 7.8 & 36.9 \\
M22 & LHon & 61.4 & 15.8 & 40.9 & 38.3 & 12 & 28 & 64.5 & 6.9 & 41.2 \\
M32 & LHon & - & - & - & 45.7 & 15.4 & 25.1 & - & - & - \\
M1-9 & LHon & 54.3 & 16.2 & 36.9 & 42.3 & 7.5 & 22.4 & - & - & - \\
M1-15 & - & 46.6 & 16.2 & 30 & - & - & - & - & - & - \\
M1-21 & LHon & 55.9 & 16.8 & 33.9 & 44.2 & 9.2 & 29.7 & 62.3 & 5 & 35.9 \\
\hline
\end{tabular}

According to the whitish tone observed in the engobe layers (i.e., of sample M6, Figure 3e), the values of $a^{*}$ were lower (between 1-8) and those of $L^{*}$ higher (more clustered between 62 and 68) (Figure 4b,c, and Table 2) than those detected in the pastes.

Conversely, the glaze was the layer with the greatest color parameter variability (Figure $4 \mathrm{e}-\mathrm{g}$ and Table 2), very possibly due to their different compositions. Following the classification of types of glaze depending on color in Table 1, two major groups could be distinguished: dark green and light honey glazes. The first one stood out for having lower chromatic values than engobes, with $\mathrm{L}^{*}$ between 34 and 43 , $\mathrm{a}^{*}$ between 0 and 11 , and $\mathrm{b}^{*}$ between 0 and 15 . The second type had intermediate values between the green glaze type and the color of the pastes, with $L^{*}$ values between 38 and 49 , $\mathrm{a}^{*}$ between 5 and 16 , and $b^{*}$ between 14 and 30 . There was also a third type of glaze that was light green in color with shades in between the two glazes. The only two samples of this type (M19 and M20) had an $L^{*}$ between 41 and 50 , a* between 1.8 and 2 , and $\mathrm{b}^{*}$ between 13 and 21 .

\subsection{Fourier Transform Infrared (FTIR)}

To facilitate the subsequent mineralogical characterization, a preliminary analysis of the pastes was carried out using infrared spectroscopy, in which the anionic groups (carbonates, silicates...) were identified in the samples.

The characteristic signals of quartz $\left(\mathrm{SiO}_{2}\right)$ were identified in all of the spectra collected from the pastes: $\mathrm{Si}-\mathrm{O}$ symmetric stretching band at $780 \mathrm{~cm}^{-1}$ ( $\left.\mathrm{sym} v \mathrm{Si}-\mathrm{O}\right)$, asymmetric stretching at $1050 \mathrm{~cm}^{-1}$ (asym $v \mathrm{Si}-\mathrm{O}$ ), and also a small band in the shoulder of the asymmetric stretching at $1160 \mathrm{~cm}^{-1}$ (asym $v \mathrm{Si}-\mathrm{O}$ ) [20,21] (Figure 5). Carbonate signals were only were present in a few of them and with low intensity (M1, M6, M8, M9, and M1-9 samples) (Figure 5). In these ones, out-of-plane $\mathrm{CO}_{3}{ }^{-2}$ bending vibrations appeared at $875 \mathrm{~cm}^{-1}$ (oop $\delta \mathrm{CO}_{3}{ }^{-2}$ ) and the asymmetric $\mathrm{CO}_{3}{ }^{-2}$ stretching at $1460 \mathrm{~cm}^{-1}$ (asym $\vee \mathrm{CO}_{3}{ }^{-2}$ ), which meant the presence of recarbonated calcite $\left(\mathrm{CaCO}_{3}\right)[22,23]$ (Figure 5). There were no signals of other silicates or silicoaluminates such as plagioclase minerals $\left((\mathrm{Na}, \mathrm{Ca})(\mathrm{Si}, \mathrm{Al})_{4} \mathrm{O}_{8}\right)$, which usually appear between 950 and $1150 \mathrm{~cm}^{-1}$; micas $\left(\mathrm{KAl}_{2}\left(\mathrm{AlSi}_{3} \mathrm{O}_{10}\right)(\mathrm{OH})_{2}\right)$ around $1000 \mathrm{~cm}^{-1}$; or potassium feldspars $\left(\mathrm{KAlSi}_{3} \mathrm{O}_{8}\right)$, between 1040 and $1110 \mathrm{~cm}^{-1}$, very possibly 
due to the wide signal of the quartz [24]. In the following sections, additional mineralogical information will be provided.

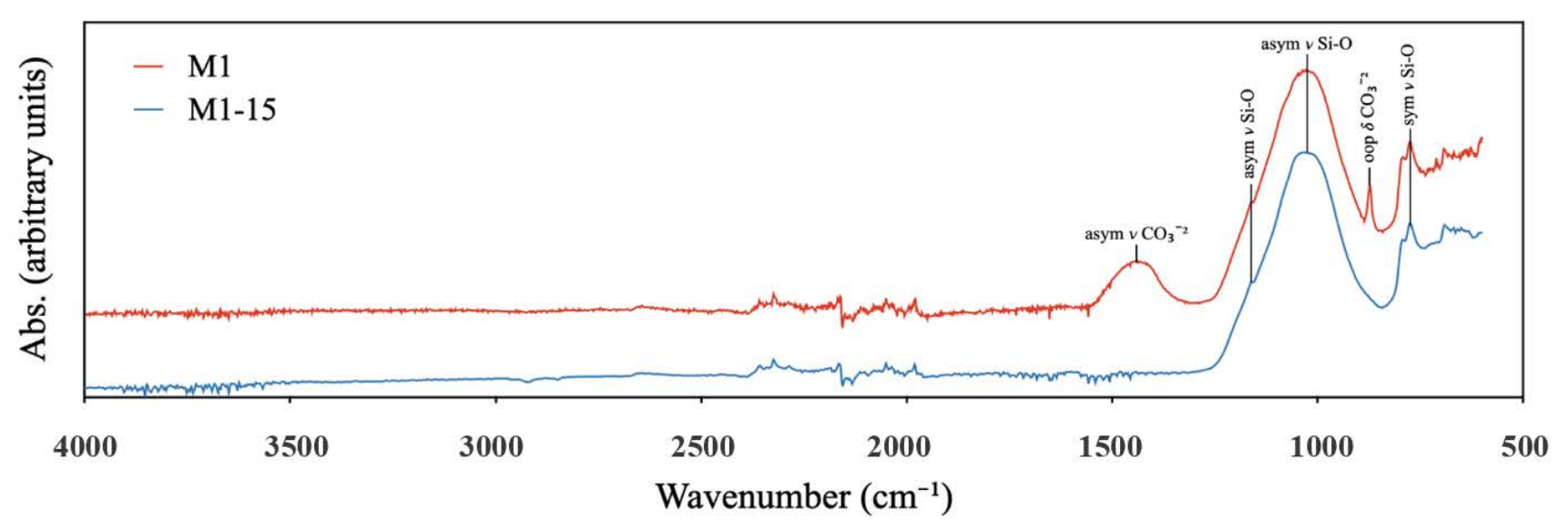

Figure 5. Infrared spectra of samples M1 (red spectrum) and M1-15 (blue spectrum).

\subsection{Differential Thermal Analysis-Thermogravimetry Analysis (DTA-TG)}

The DTA-TG results corroborated the results by FTIR. Quantitative analyses were done using TG. Carbonates in a minimum proportion were detected in some of the pastes (M1, M6, M8, M9, and M1-9), since the mass loss of $\mathrm{CO}_{2}$ between 600 and $1000{ }^{\circ} \mathrm{C}$ was on average $0.26 \%$. The DTG peak of decarboxylation was recorded between $650-700{ }^{\circ} \mathrm{C}$ in all the cases, which could indicate that calcite is secondary [16]. The amount of organic matter and structural water (mass loss between 200 and $600{ }^{\circ} \mathrm{C}$ ) was also very low, with $0.45 \%$ on average. These results matched with those by FTIR, in which neither free water $\mathrm{H}_{2} \mathrm{O}, \mathrm{OH}^{-}$ groups, nor organic molecule signals appeared between 3000 and $4000 \mathrm{~cm}^{-1}$ (Figure 5). The scarcity of calcite, the fact of it being secondary, and also the lack of structural $\mathrm{OH}^{-}$ groups could indicate that the pastes of the tiles were fired above $750-800{ }^{\circ} \mathrm{C}$ [17].

\subsection{X-Ray Fluorescence (XRF) Spectroscopy}

The identification of the major chemical elemental composition of each of the layers and the determination of their relative proportions are crucial for the classification of the carreaux de pavement as have been shown in the bibliography. Semiquantitative elemental chemical analyses also help in the identification of mineralogical phases and their amount.

The X-ray fluorescence spectra showed that the pastes had high relative contents of $\mathrm{Si}(\mathrm{K} \alpha$ at $1.74 \mathrm{keV}), \mathrm{Fe}(\mathrm{K} \alpha$ at $6.40 \mathrm{keV}), \mathrm{Al}(\mathrm{K} \alpha$ at $1.49 \mathrm{keV}), \mathrm{Ca}(\mathrm{K} \alpha$ signal at $3.69 \mathrm{keV})$, and $\mathrm{K}(\mathrm{K} \alpha$ signal at $3.31 \mathrm{keV})$. $\mathrm{Mg}, \mathrm{Pb}, \mathrm{Ti}$, and $\mathrm{V}$ were also detected. The samples in which carbonates were detected by FTIR spectroscopy and DTA-TG had a higher proportion of Ca such as in sample M1 compared to M1-15 (Figure 6a). The high intensity of Si matched the presence of silicates (quartz) by FTIR.

The engobe stood out for its lower proportion of $\mathrm{Fe}$ and $\mathrm{Ca}$ and higher proportion of $\mathrm{Si}$, $\mathrm{Al}$, and especially $\mathrm{Pb}(\mathrm{L} \alpha$ and $\mathrm{M} \alpha$ at 10.55 and $2.34 \mathrm{keV}$, respectively), probably coming from the layer of glaze that covered the engobe (Figure $6 \mathrm{~b}$ showed the spectra of two of the samples, M13 and M33). Manual separation of both layers and separate analysis was not possible due to their low thickness and high fragility. Better results were achieved thanks to the analysis of the cross-sections by SEM-EDS.

The composition of the glazes was characterized by the significant proportion of lead and silicon (Figure 6c shows the spectra collected on some of the samples, M1, M10, M19, M23, and M32). None of the spectra of the glazes showed Sn. Furthermore, in sample M10 (with dark green color), a slight signal of $\mathrm{Cu}(\mathrm{K} \alpha$ at $8.05 \mathrm{keV})$ appeared. 

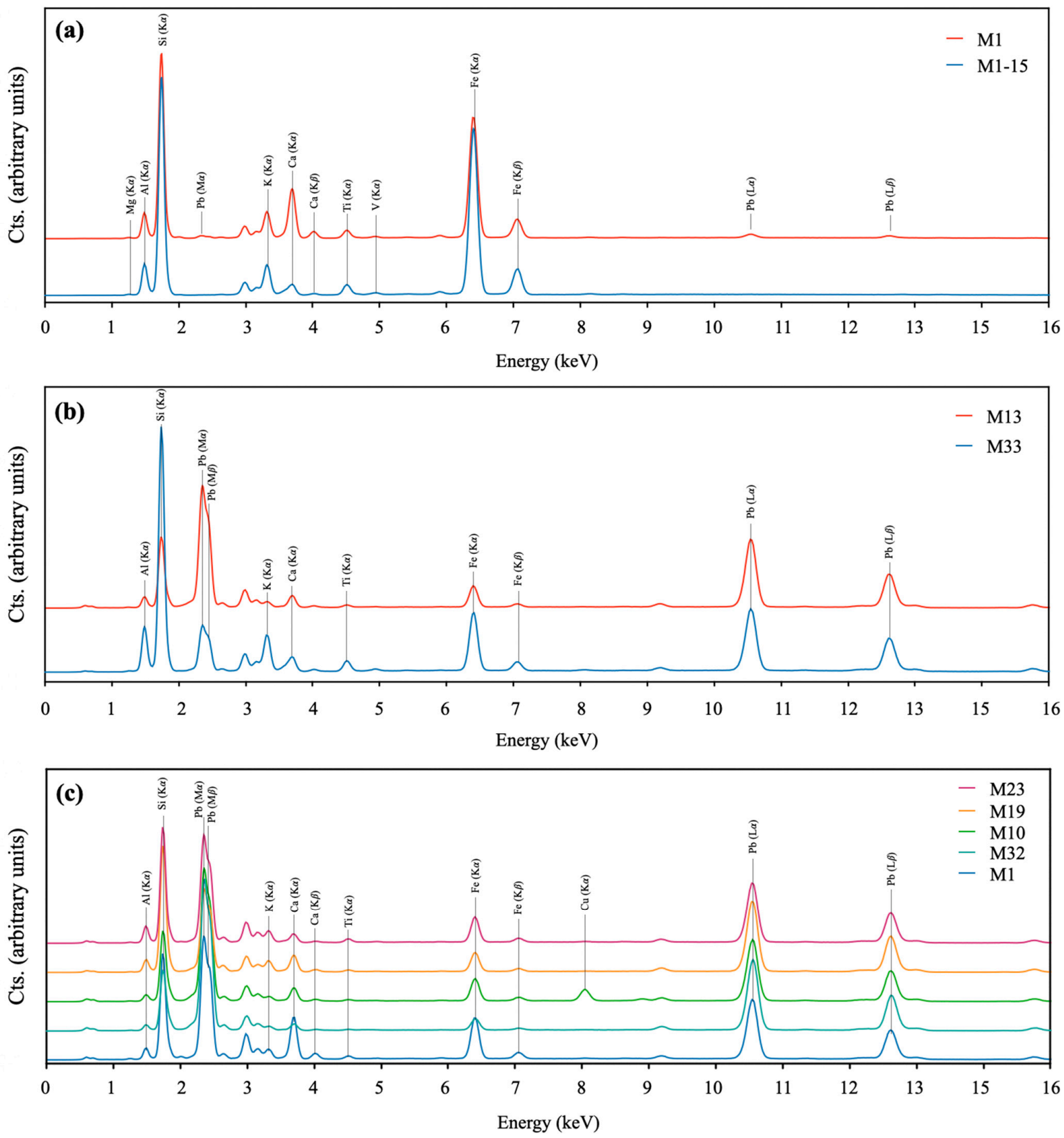

Figure 6. XRF spectra of (a) the paste of samples M1 and M1-15; (b) glaze and engobe of samples M13 and M33; (c) glaze of samples M1, M10, M19, M23 and M32.

Semiquantitative analyses were performed taking into account the intensities of the peaks of each element ( $\mathrm{M} \alpha$ for $\mathrm{Pb}$ and $\mathrm{K} \alpha$ for all the others) and the ratios with that from the Si K $\alpha$ peak (Table 3). One of the main differences between the two main glaze groups (dark green and light honey) was their relative proportion of lead, which was greater in the honey glazes compared to the dark green in general terms. Some other slight differences were also found in the Fe/Si ratio, with being the honey glaze somewhat richer in Fe. In the $\mathrm{Ca} / \mathrm{Si}$ and $\mathrm{Al} / \mathrm{Si}$ ratios, there were no important differences between both types of glaze. As for the comparison between the three layers (glaze, engobe, and paste) (Table 3), glazes and engobes had much more lead and much less iron than the pastes; engobes and pastes had more potassium than the glazes; and the $\mathrm{Al} / \mathrm{Si}$ ratios were higher in the engobes than in the glazes and pastes. 
Table 3. Relative elemental semi-quantification of the samples taking into account the intensity (counts) of the peaks and comparing them with $\mathrm{Si}(\mathrm{K} \alpha$ at $1.74 \mathrm{keV})$ as a reference.

\begin{tabular}{ccccccc}
\hline Sample & $\mathbf{P b}(\mathbf{M} \boldsymbol{\alpha}) / \mathbf{S i}$ & $\mathbf{A l}(\mathbf{K} \boldsymbol{\alpha}) / \mathbf{S i}$ & $\mathbf{F e}(\mathbf{K} \boldsymbol{\alpha}) / \mathbf{S i}$ & $\mathbf{K}(\mathbf{K} \alpha) / \mathbf{S i}$ & $\mathbf{C a}(\mathbf{K} \boldsymbol{\alpha}) / \mathbf{S i}$ & $\mathbf{C u}(\mathbf{K} \alpha) / \mathbf{S i}$ \\
\hline M1 glz DGre & 1.1575 & 0.1109 & 0.3958 & 0.1004 & 0.4005 & 0.0157 \\
M10 glz DGre & 1.8962 & 0.0987 & 0.3264 & 0.0741 & 0.1933 & 0.1743 \\
M6 glz DGre & 0.9807 & 0.1187 & 0.3195 & 0.0852 & 0.0672 & 0.0142 \\
M23 glz LGre & 0.9333 & 0.1458 & 0.2244 & 0.1063 & 0.0799 & 0.0151 \\
M19 glz LHon & 0.6613 & 0.1 & 0.1556 & 0.0916 & 0.1365 & 0.0111 \\
M21 glz LHon & 1.4357 & 0.119 & 0.7653 & 0.0962 & 0.3346 & 0.0195 \\
M22 glz LHon & 2.1813 & 0.1416 & 0.4187 & 0.1128 & 0.3807 & 0.0209 \\
M32 glz LHon & 2.5358 & 0.1003 & 0.2036 & 0.0791 & 0.118 & 0.0217 \\
Paste mean & 0.0113 & 0.1368 & 0.6726 & 0.1326 & 0.1459 & 0.0077 \\
Engobe mean & 0.9472 & 0.1706 & 0.2749 & 0.121 & 0.118 & 0.0145 \\
\hline
\end{tabular}

\subsection{Petrographic Microscopy (PM)}

The mineralogical identification of the pastes started with petrographic analyses performed on thin sections of $9 \mu \mathrm{m}$ thick, in which quartz, calcite, and hematite crystals were identified as embedded in a reddish matrix (Figure 7). Hematite was very possibly the compound responsible for the coloration of the pastes [25-27]. The most abundant mineral was quartz, as previously detected by FTIR.
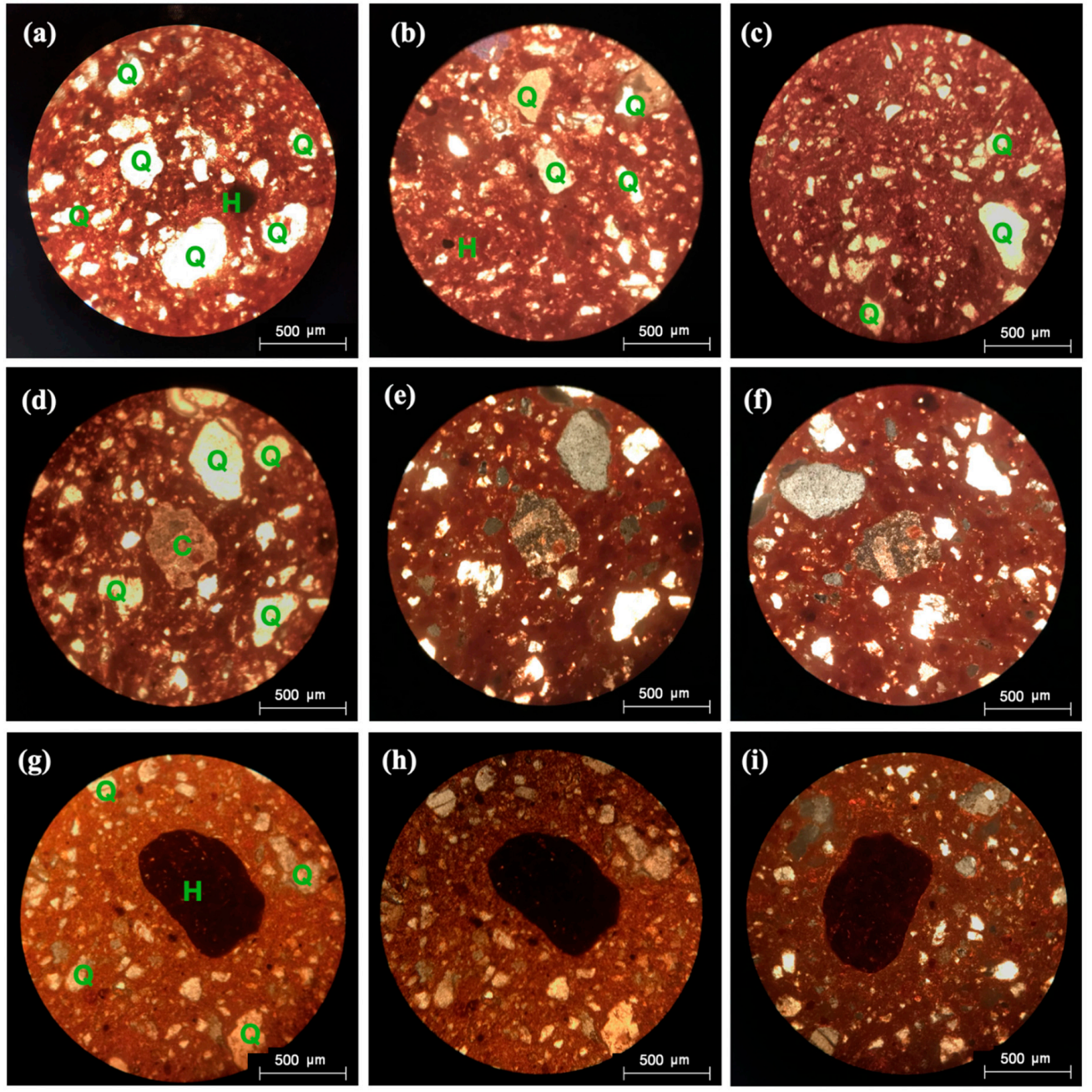

Figure 7. Thin section of the pastes of the M1-51 (a,b,d-f) and M1-52 (c,g-i). Samples images collected under a petrographic microscope $(100 \times)$. Aleatory captures for modal análisis $(\mathbf{a}-\mathbf{c})$. Capture of a region of a small crystal of calcite $(\mathbf{d}-\mathbf{f})$ and hematite (g-i), with parallel $(\mathbf{d}, \mathbf{g})$ and crossed nicols at $0^{\circ}(\mathbf{e}, \mathbf{h})$ and $90^{\circ}(\mathbf{f}, \mathbf{i})$. 
The surface occupied by quartz crystals was large enough to be well defined and was approximated by modal analysis, resulting in $12-20 \%$, whilst $80-88 \%$ corresponded to the reddish matrix. Regarding the granulometry of the minerals, quartz had a size of 50 to $800 \mu \mathrm{m}$ (similarly to those measurements by OM) and those of calcite and feldspar between 30 and $200 \mu \mathrm{m}$. The reddish matrix particles had a grain size lower than $50 \mu \mathrm{m}$. Therefore, in particle size terms, the tile pastes would be composed of a mixture of fine sand, silt, and clays [28].

\subsection{X-Ray Diffraction (XRD)}

In addition to the minerals identified in the pastes by PM, the XRD analyses showed the presence of other minor minerals phases such as dolomite $\left(\mathrm{CaMg}\left(\mathrm{CO}_{3}\right)_{2}\right)$, gehlenite $\left(\mathrm{Ca}_{2} \mathrm{Al}(\mathrm{SiAl}) \mathrm{O}_{7}\right)$, potassium feldspars $\left(\mathrm{KAlSi}_{3} \mathrm{O}_{8}\right)$, and micas $\left(\mathrm{K}(\mathrm{Al}, \mathrm{Fe}, \mathrm{Mg})_{2-3}\left(\mathrm{AlSi}_{3} \mathrm{O}_{10}\right)(\mathrm{OH})_{2}\right)$ (Table 4). Quartz was the most abundant crystalline phase detected by XRD (Table 4). Hematite was present in all pastes. As aforementioned, this compound provided the reddish color to the pastes [25-27]. The mineralogical composition of the pastes was very similar in all tiles; therefore, the location of the artifacts (Northern Hall, landfill, or out of context) was not an important factor to differentiate among them. These results indicated a good homogeneity in the tile pastes from a compositional point of view and few affectation of the environment of the places where they were found. Samples M1, M6, M8, M9, and M1-9 showed the presence of calcite reflections at $2 \theta=29.406,39.402,43.146$ (file 05-0586) (Figure 8a), matching the results provided by other techniques.

Table 4. Minerals phases identified in each sample of paste by x-ray diffraction (XRD) and its abundance (+++: abundant; ++: moderate; +: minority; nd: not detected). Abbreviations: Q—quartz (file 33-1161); C—calcite (file 05-0586); H-hematite (file 33-0664); KF-potassium feldspar (files 89-8673 and 19-0931); D—dolomite (file 36-0426); G—gehlenite (file 35-0755); $\mathrm{M}$-mica (file 46-0741).

\begin{tabular}{|c|c|c|c|c|c|c|c|c|c|c|c|c|c|c|c|}
\hline Sample & $\mathbf{Q}$ & $\mathrm{C}$ & $\mathbf{H}$ & $\mathbf{K F}$ & $\mathrm{D}$ & G & $\mathbf{M}$ & Sample & $\mathbf{Q}$ & $\mathrm{C}$ & $\mathbf{H}$ & $\mathbf{K F}$ & $\mathrm{D}$ & $\mathbf{G}$ & $\mathbf{M}$ \\
\hline M1 & +++ & ++ & + & + & nd & + & nd & M13 & +++ & + & + & + & + & + & nd \\
\hline M3 & +++ & + & + & nd & + & + & nd & M19 & +++ & + & + & + & nd & + & + \\
\hline M5 & +++ & + & + & + & + & + & nd & M20 & +++ & + & + & + & nd & nd & + \\
\hline M6 & +++ & ++ & + & + & + & nd & nd & M1.15 & +++ & nd & + & + & + & nd & nd \\
\hline M23 & +++ & + & + & + & + & + & nd & M1-50 & +++ & + & + & + & nd & + & + \\
\hline M4 & +++ & + & + & + & + & + & + & M1-9 & +++ & + & + & + & + & nd & + \\
\hline M8 & +++ & ++ & + & + & + & nd & nd & M21 & +++ & + & + & + & + & + & + \\
\hline M9 & +++ & ++ & + & + & + & nd & nd & M22 & +++ & + & + & + & + & nd & + \\
\hline M10 & +++ & + & + & + & + & + & nd & M1-21 & +++ & + & + & + & + & nd & + \\
\hline
\end{tabular}

In the pastes of sample M19, some differences were observed between the red and grey zones. In the M19r (red) diffractogram, hematite appeared at $2 \theta=33.153,35.612,57.091$ (file 33-0664), while in the M19g (grey), hematite was not detected (Figure 8b). However, in the XRF spectra, the Fe content in both zones was practically identical, so the difference must lie in a different mineralogical form of iron. In sample $\mathrm{M} 19 \mathrm{~g}$, some of the main reflections of wüstite (FeO) seemed to be distinguished at $2 \theta=41.71,60.92,35.22$ (file 01-1223) [29-31].

The engobes (Figure 8c shows the XRD diagrams of samples M13 and M33) were formed by a lead silicoaluminate $\left(\mathrm{PbAl}_{2} \mathrm{Si}_{2} \mathrm{O}_{8}\right)$ phase [32]. The main reflections of this phase appeared at $2 \theta=35.02,35.05,34.90$ (file 25-0428). The high ratio Al/Si of this type of silicoaluminate matched the $\mathrm{Al} / \mathrm{Si}$ ratio found by XRF spectroscopy in the engobes of the tiles. The mean value of the engobes was 0.17, higher than in the other two strata: 0.14 in pastes and 0.12 in the glazes (mean values). The absence of calcite in the engobes was also an important result since it allowed confirmation that the whitish color of the engobe was caused only by silicoaluminate. Furthermore, the engobe of sample M33 also showed a certain amount of quartz and mica. 

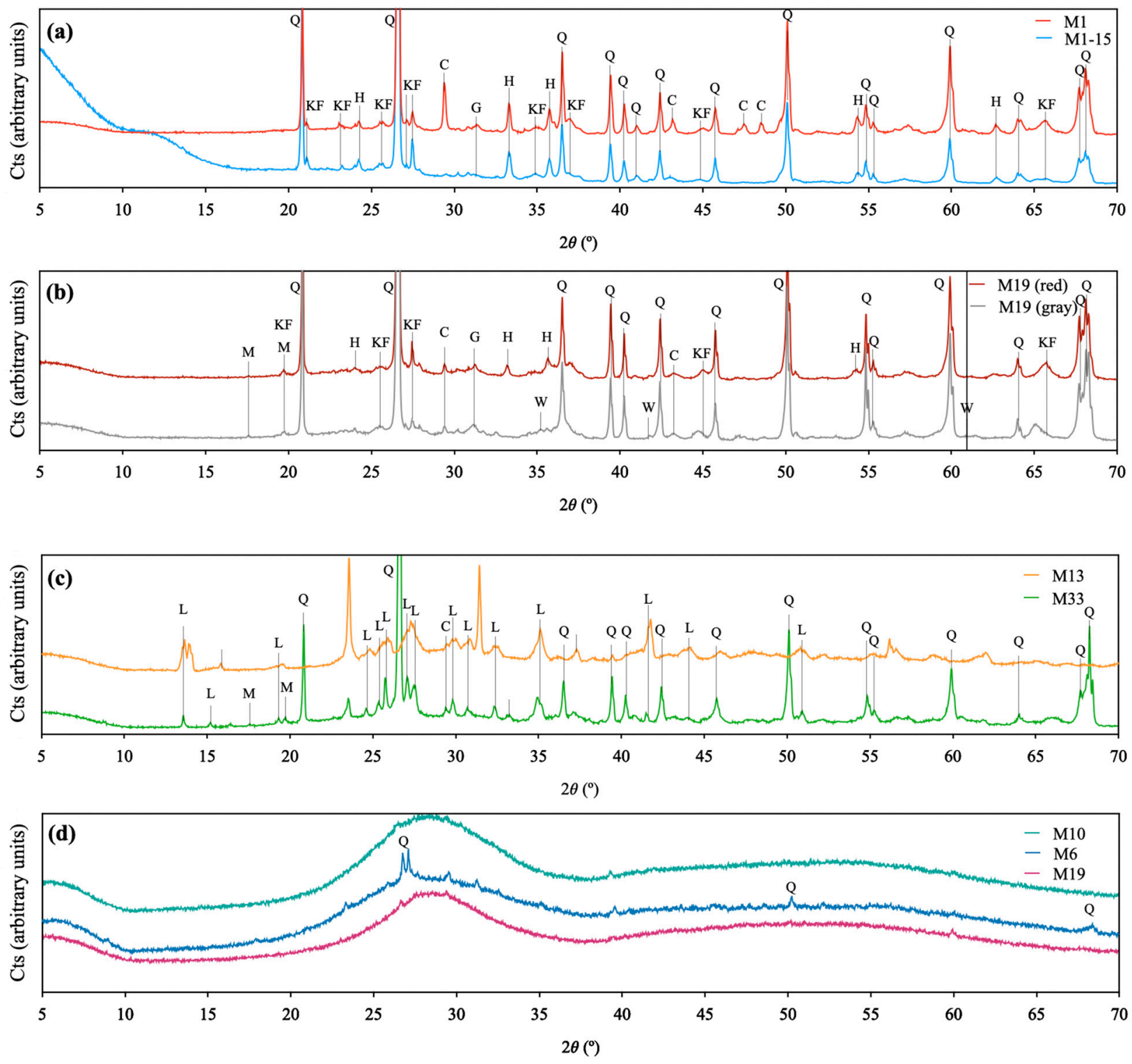

Figure 8. X-ray diffraction patterns of: (a) paste samples M1 and M1-15; (b) the two paste colors of tile M19 (red and grey); (c) engobe samples M13 and M33; (d) glazes of M6, M10 and M19. Abbreviations: Q— quartz; C—calcite; H-hematite; KF-potassium feldspar; D—dolomite; G—gehlenite; M-mica; W—wüstite; L—lead silicoaluminate.

The XRD analysis of the glazes hardly provided any information on their composition since very wide signals appeared in the diffractograms (Figure $8 \mathrm{~d}$ shows the XRD diagrams of samples M6, M10, and M19). The broad signals seen in the diffractogram indicated an amorphous arrangement. Lead oxide, used as a flux, reduces the melting point, thus creating a mixed amorphous vitreous layer (glaze). The absence of crystalline mineral phases could be also an indication that the firing temperature was high enough for the glaze to form a homogeneous vitreous layer. In the glaze of sample M6, some quartz peaks could be identified. Phases responsible for the honey and dark green glazes were not detected.

\subsection{Scanning Electron Microscopy Coupled with Energy Dispersive X-Ray Spectroscopy (SEM-EDS)}

According to the secondary electron images by SEM of the cross-sections, the glazes were seen as compact and homogeneous layers, except for the air bubbles of different sizes that were also clearly visible. As an example, the OM and SEM images of sample M6 
and the EDX mappings corresponding to some elements ( $\mathrm{Si}, \mathrm{Al}, \mathrm{Fe}, \mathrm{Pb}, \mathrm{K}, \mathrm{Ti}$ and $\mathrm{Ca}$ ) are shown in Figure 9. The glazes stood out for their high Pb content (Figure 9f), as previously indicated by the XRF analyses. Although the honey glaze color was assigned to iron-based compounds, the distribution of iron in the mapping was rather homogeneous within the cross-sections (Figure 9e) due to the presence of hematite (and wüstite) in pastes as detected by $\mathrm{PM}$ and XRD. From the mapping, the composition of glazes was based on $\mathrm{Pb}, \mathrm{Si}, \mathrm{Al}$, and Fe-compounds.
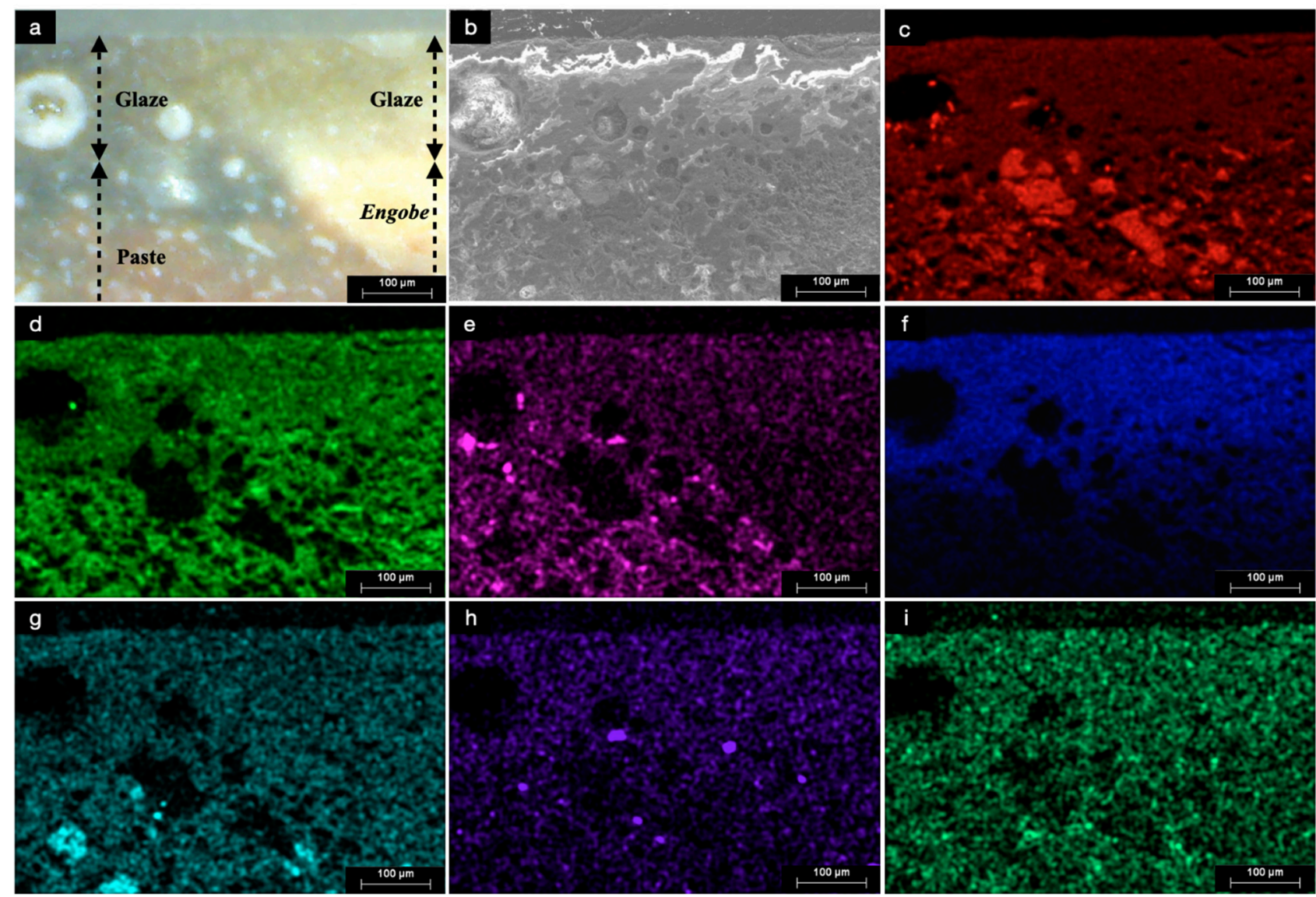

Figure 9. Images $(200 \times)$ collected using: (a) Optical microscopy $(\mathrm{OM}),($ b) scanning electron microscopy (SEM); energy dispersive x-ray spectroscopy (EDS) mappings corresponding to: (c) $\mathrm{Si}$, (d) $\mathrm{Al}$, (e) Fe, (f) $\mathrm{Pb}$, (g) K, (h) Ti, and (i) Ca.

The engobe and paste layers appeared morecontinuous and homogeneous, without air bubbles. The engobes showed compositions mainly based on $\mathrm{Si}$ and $\mathrm{Al}$ (Figure 9c,d). Quartz crystals also appeared, but smaller than those of the pastes (Figure 9c). The EDS mappings made a better determination of the composition of the engobe possible without the lead contamination coming from the upper glaze layers (as aforementioned in the XRF analyses). Therefore, a kaolinite-type silicoaluminate would be very possibly present in this layer.

The pastes appeared as a mixture of large Si-based crystals, assigned to quartz, previously observed by PM, XRD, FTIR, and XRF spectroscopy, but also Ti-based compounds (Figure $9 \mathrm{~h}$ ), which were not detected by XRD. In addition, some crystals rich in $\mathrm{K}$ (Figure $9 \mathrm{~g}$ ), which were assigned to the potassium feldspars detected by XRD; some areas with a higher distribution of Fe appeared throughout the pastes, matching with that described in the XRF spectroscopy section. 


\section{Discussion}

According to Metreau et al. [13], the tiles of the 13th century were thicker $(2.3-2.7 \mathrm{~cm})$ than those of the 14th century, which ranged from 1.6 to $2.2 \mathrm{~cm}$, reducing mass and costs in the latter. The tiles of Tiebas Castle were dated to around 1256 [4] and their thicknesses ranged from 2.1 to $2.8 \mathrm{~cm}$. Therefore, they matched the 13th century production of carreaux de pavement. This result provided a first datum about the possible date of manufacturing of the artifacts, which must be corroborated by other complementary techniques.

\subsection{Paste}

The composition of the pastes of the Tiebas tiles turned out to be quite homogeneous. There were no significant differences in composition depending on the locations in which the tiles were found (Northern Hall, landfill, or out of context). It stood out mainly for its high quartz content, identified by most techniques (OM, FTIR spectroscopy, XRF spectroscopy, PM, XRD, SEM-EDS). This quartz had a variable grain size, from the largest grains observable by OM (ca. $800 \mu \mathrm{m})$ to the smallest observable by SEM-EDS (less than $50 \mu \mathrm{m})$. The appearance of sandstone pebbles and metallic inclusions by OM indicated a certain carelessness in kneading and modeling the pastes.

Another important characteristic of the Tiebas pastes was the low content of carbonates, especially calcite, detected by thermal analyses, PM, and XRD. Although some variability in the calcite content was detected, none of the samples exceeded $4.7 \%$ in mass. The vibrational frequency at which the asymmetric $\mathrm{CO}_{3}{ }^{-2}$ stretching signal appeared in FTIR spectroscopy [16], together with the decarbonation maximum temperature of DTG, indicated that this calcite was very probably secondary [22]. These data allowed us to provide an approximate firing temperature above $750-800{ }^{\circ} \mathrm{C}$ [17]. The samples with recarbonated calcite and those without calcite showed an important difference in the relative content of $\mathrm{CaO}$ by XRF spectroscopy (Figure 6), which matched the FTIR results (Figure 5). The calcite formation probably originated from the inclusion of some limestone pebbles, as it could be seen by OM (Figure 3a) and PM (Figure 7d-f).

Literature about carreaux de pavement, devoted to mainly to French artifacts, distinguishes two types of tiles depending on the content of $\mathrm{CaO}$ in the pastes. The first type has high proportions of 13-30\% [12] relative to a deposit in the Bourges region. The second, in contrast, reports low $\mathrm{CaO}$ concentrations in pastes: $1-2 \%$ in the region of Bordeaux [5,6], $1-3 \%$ in Alsace [15], and $1-2 \%$ for the 13 th century and $0.2-1 \%$ for the 14 th century, in Bretagne [13]. From the data provided by the thermal analysis in the Tiebas pastes, values of $\mathrm{CaO}$ between $0.1-2.6 \%$ were calculated. Therefore, the Tiebas samples would be similar to those of Bordeaux, Alsace, and Bretagne but different from those of Bourges.

The greyish color detected in two of the tile pastes (samples M19 and M20) contrasted with the reddish-orangish color observed in the majority of the tiles, which can be related to the absence of hematite (identified in the rest of the tiles by PM and XRD). Wüstite (iron II oxide that has a grayish color) was detected in these two tiles by XRD, very possibly due to the presence of a partial reducing atmosphere during the high temperature heating [29-31]. This heating with a reducing atmosphere could take place during the firing of the tiles in some areas inside the kiln, where oxygen is scarce. It is known that in the summer of 1378 , the castle was burned down and the wooden ceilings over the tiled pavement burned down [4]. The abundance of burning wood and the absence of enough oxygen could cause the reducing atmosphere.

It was also possible to identify other more minor mineral phases such as titaniumbased compounds by SEM-EDS (possibly titanium oxide), micas (PM, XRF spectroscopy), potassium feldspar (XRF spectroscopy, XRD, SEM-EDS), and gehlenite (XRD). The presence of these compounds did not coincide with the geology of the Pamplona Basin where Eocene marls and limestones predominate [33]. With the current data, it is most likely that the tiles were made in northern France, where this type of tile is typical [1-3]. From these results, a fluid trade between France regions and Northern Spain could be inferred. This subject will be deeply dealt with in another investigation in progress. 
The presence of gehlenite would imply that the firing temperature was not higher than $1000^{\circ} \mathrm{C}$, since at this temperature it decomposes to anorthite. Another aspect to consider is that the gehlenite neoformation could occur from $800^{\circ}$, although it could already have been present in the raw clay [34].

\subsection{Engobe}

The engobe was mainly composed of lead silicoaluminate ( $\left.\mathrm{PbAl}_{2} \mathrm{Si}_{2} \mathrm{O}_{8}\right)$ (XRD), at least in its superficial part where engobe and glaze were hardly distinguishable. The assumption is that the original silicoaluminate compound forming the engobes was kaolinite $\left(\mathrm{Al}_{2} \mathrm{Si}_{2} \mathrm{O}_{5}(\mathrm{OH})_{4}\right)$, which transformed to metakaolinite $\left(\mathrm{Al}_{2} \mathrm{Si}_{2} \mathrm{O}_{7}\right)$ after heating at $550{ }^{\circ} \mathrm{C}$, and reacted with lead compounds of the glaze [34]. Cicuttini et al. [5] mentioned the use of kaolinite in the engobes. No significant differences were found between the engobes of the different locations within the Castle.

Depending on the engobe composition, two types of tiles were differentiated in the literature about the carreaux de pavement: those that used some type of silicoaluminate, with $68-73 \%$ of $\mathrm{SiO}_{2}$ and $19-22 \%$ of $\mathrm{Al}_{2} \mathrm{O}_{3}$ [5,6]; or those that mainly employed $\mathrm{CaO}(30-40 \%$ of $\mathrm{CaO}$ [12] or $8 \%$ from Haute-Vienne [14]). The engobe of the analyzed samples from Tiebas would be again similar to those from the Bordeaux region.

\subsection{Glaze}

Only dark glazes were found in the Northern Hall. The glazes found in the landfill were both dark green and honey and also included the only two samples with light glaze (M19 and M20). The tile fragments found out of archaeological context on the slopes of the castle hill were mostly the honey type, except for sample M1-15, which belonged to the dark green glaze type. In all cases, the glaze consisted of a compact (OM, SEM-EDS) and mostly amorphous (XRD) layer of about 100-500 $\mu \mathrm{m}$ thick (OM, SEM-EDS). The glazes appeared to have different thicknesses depending on whether they were on the paste or on the engobe, as can be seen in Figure 2e (OM). The thickness coincided with those described in [6].

High relative contents of lead and silicon (XRF spectroscopy, SEM-EDS) and the absence of tin (XRF spectroscopy, SEM-EDS) were detected. The presence of lead and the absence of tin allowed them to be classified as plumbiferous glazes [35-37], which are characteristic of a specific historical period [13]. As with the pastes and the engobes, the glazes can be classified into two types according to the information extracted from the articles published about the carreaux de pavement. The first type of glaze is that which uses only lead compounds as a flux. Lead oxide appeared in a concentration of 35-45\% [12], 32-69\% [5,6], $39-62 \%$ [13], and 51-65\% [14]. The other type of glaze is that which uses a mixture of lead and tin compounds as a flux; the quantities of lead and tin oxides was respectively $20-42 \%$ and $7-36 \%$ [12], 50-68\% and $0.2-1.4 \%$ [13], and $8-11 \%$ in tin oxide [14]. The lead glaze seems to be more characteristic of the 13 th century carreaux de pavement $[5,6,13,14]$, whilst the lead and tin glaze appeared only from the 14th century [12-14]. The tiles from Tiebas Castle would be within the first group, therefore, they could again be associated with manufacture in the 13th century [4] and with production in the Bordeaux area [5,6]. One drawback is that stylistically, it does not coincide with the decorative motifs of the sites in the Bordeaux region, but it does coincide with the Champagne region [1-3].

The two main sources of lead throughout history have been the roasting of galena $(\mathrm{PbS})$ and the calcination of lead carbonates, generally cerussite $\left(\mathrm{PbCO}_{3}\right)$ or hydrocerussite $\left(\mathrm{PbCO}_{3} \cdot 2 \mathrm{H}_{2} \mathrm{O}\right)[38,39]$. The small bubbles that appear in the glaze (Figures 2c-e and 9a,b) could indicate the use of lead carbonates as a source of lead for the glaze [39-42], since from $350-450{ }^{\circ} \mathrm{C}$, it decomposes into $\mathrm{CO}_{2}$ and $\mathrm{PbO}$ [43]. These bubbles are frequent in glazes that do not reach a sufficient temperature $\left(900-1000^{\circ} \mathrm{C}\right)$, when the viscosity of the glaze is optimal [39].

Regarding the different types of glaze found in Tiebas, the dark glaze was characterized by a lower proportion of $\mathrm{Pb}$ (Table 3). The honey glaze, however, was much more transparent and had a higher $\mathrm{Pb} / \mathrm{Si}$ ratio (Table 3 ). The remaining ratios of major elements 
( $\mathrm{Al} / \mathrm{Si}, \mathrm{Fe} / \mathrm{Si}, \mathrm{K} / \mathrm{Si}, \mathrm{Ca} / \mathrm{Si}$ ) were similar between them, and were slightly lower than the ratios found in the pastes (Table 3). This could mean that similar clays were employed for the fabrication of glazes. Light green glazes appeared associated with the only two samples with grayish pastes (M19 and M20), which indicated that the color of the glazes were possibly influenced by those of the inner layers.

As aforementioned, a slight signal of $\mathrm{Cu}(\mathrm{K} \alpha$ at $8.05 \mathrm{keV})$ appeared in one of the samples. The use of copper-based pigments has also been identified in other French tiles $[5,6,13]$ in which copper is only applied on monochromatic tiles [13].

\section{Conclusions}

This study dealt with the unique carreaux de pavement found in the Iberian Peninsula. Thanks to an in-depth mineralogical investigation, the composition of the three layers of tiles from the Tiebas Castle was fully determined. The pastes were composed of quartz, potassium feldspar, mica, calcite, and hematite, the latter providing their characteristic orangish-reddish color. Silicoaluminate compounds (very probably kaolinite) were the main compound found in the engobe. Glazes were mainly composed of lead-based compounds and quartz. Honey glazes were richer in iron, and copper was detected in one of the dark green glazes. The heating temperature of the pastes was inferred above $750-800{ }^{\circ} \mathrm{C}$ and below $1000^{\circ} \mathrm{C}$. There were no important differences between the tiles found in the three locations within the Castle.

The carreaux de pavement tiles from Tiebas matched those manufactured in the Bordeaux region, which is relatively close to Navarre, more than those from other regions (Alsace, Bretagne, and Bourges). However, stylistically they did not coincide with them, being much more similar to those of the Champagne and Reims regions, of which, unfortunately, there have been no archaeological studies.

The comparison with the scarce articles devoted to carreaux de pavement has allowed for the dating of the Tiebas tiles to the 13th century, coinciding with the date of the construction of the castle that is given by historical and archaeological references. The dating was mainly possible thanks to the presence of plumbiferous glazes, characteristic of the carreaux de pavement of that century.

This article provides new information to include in the corpus of the carreaux de pavement made in Europe in medieval times and provides meaningful work to aid future researchers in this subject.

Author Contributions: Conceptualization: I.R.-A., E.L., and A.D.; Methodology: I.R.-A.; Software: I.R.-A.; Validation: I.R.-A., E.L., A.D.; Formal Analysis: E.L., A.D.; Investigation: I.R.-A., E.L., A.D.; Resources: I.R.-A., E.L., A.D.; Data Curation: I.R.-A., E.L., A.D.; Writing-Original Draft Preparation: I.R.-A., E.L., A.D.; Writing-Review \& Editing: I.R.-A., E.L., A.D.; Visualization: I.R.-A.; Supervision: E.L., A.D.; Project Administration: I.R.-A., E.L., A.D.; Funding Acquisition: I.R.-A., E.L., A.D. All authors have read and agreed to the published version of the manuscript.

Funding: The reported study was funded by the Ayuntamiento de Tiebas-Muruarte de Reta, Fundación Sierra de Alaiz; and the Dirección General de Cultura-Institución Príncipe de Viana (Navarre Government) under the project Thibalt. Caracterización arqueométrica de Carreaux de Pavement procedentes del Castillo de Tiebas (Navarra).

Data Availability Statement: The dataset is presented directly in the present study. Additional data (unpublished) are available upon request from the corresponding author (A.D.).

Acknowledgments: The authors wish to thank the staff from the Chemistry Department of the University of Navarre, especially to Cristina Luzuriaga and Iker Arrizabalaga, for their help in the experiments. We aslo thank M.C. Jimenez de Haro (ICMSE) for the SEM-EDS analyses, and the Service of Rock and Hard Materials Preparation of Zaragoza University.

Conflicts of Interest: The authors declare no conflict of interest. 


\section{References}

1. Mayer, J.; Garrigou, P. Pavement. Carreaux de sol en champagne au moyen-âge et à la renaissance. Editions du Patrimoine 2000, 4, 393-394.

2. Norton, C. Carreaux de Pavement du Moyen Âge et de la Renaissance: Collections du Musée Carnavalet; Editions Paris-Musées: Paris, France, 1992.

3. Cailleaux, D.; Chapelot, O. Carreaux de pavement du Moyen Âge et de la Renaissance: Catalogue des collections des Musées de Chaumont et de Saint-Dizier, Haute-Marne; Musée Municipal de Chaumont et Musée Municipal de Saint-Dizier: Chaumont et Saint-Dizier, France, 1987.

4. Ramos, M. Descubrimiento de un pavimento de baldosas decoradas en el castillo-palacio de Tiebas. Trabajos de Arqueología de Navarra 2009, 21, 317-324.

5. Cicuttini, B.; Merat, A.; Ben Amara, A.; Bechtel, F. Étude stylistique et technologique des carreaux de pavement du château de Lormont (Gironde, XIII-XIV siècles). In Proceedings of the Actes du 4ème Congrès International d'Archéologie Médiévale et Moderne, Paris, France, 3-8 September 2007.

6. Cicuttini, B.; Ben Amara, A.; Bechtel, F. An investigation into the ceramic technology of the two-colour tiles of "Prince Noir" castle (Bordeaux, France, Thirteenth to Fourteenth Centuries AD). In Proceedings of the 37th International Symposium on Archaeometry, Siena, Italy, 12-16 May 2008; pp. 55-60.

7. García, M.R. La Dinastía de Champaña en Navarra. Teobaldo I, Teobaldo II, Enrique I (1234-1274); Ediciones Trea: Gijón, Spain, 2010.

8. García, M.R. Teobaldo II; Editorial Mintzoa: Pamplona, Spain, 2003.

9. Castiella, A. Informe sobre los trabajos arqueológicos realizados en el Castillo de Tiebas (Navarra). Trab. Arqueol. Navar. 1998, 13, 247-286.

10. Ramos, M. Excavaciones en el castillo de Tiebas (Navarra), primer informe provisional, 1998. Trab. Arqueol. Navar. 2001, 15, 167-213.

11. Martínez, D.; Ruiz, F.J.; Vallejo, J.M. Algunas consideraciones en torno a unas baldosas góticas decoradas y vidriadas aparecidas en la ermita de Santa Catalina en Tiebas (Navarra). Trab. Arqueol. Navar. 2011, 23, 141-160.

12. Ben Amara, A.; Gourdon-Platel, N.; Bechtel, F.; Schvoerer, M.; Bon, P. Carreaux glaçurés provenant d'un château du Duc de Berry (Mehun-sur-Yèvre, fin XIV siècle): Recherche d'indices techniques. Arch. Sci. 2005, 29, 21-34.

13. Métreau, L.; Cantin, N.; Bechtel, F.; Rosen, J.; André, P. De Suscinio I à Suscinio II: Rupture ou continuité? Étude archéométrique des carreaux décorés à glaçure transparente des pavements médiévaux du château de Suscinio (Sarzeau, Morbihan). Revue Archéol. l'Ouest 2012, 29, 243-249. [CrossRef]

14. Rouzeau, B.; Bocquet-Liénard, A.; Moulis, C. Les carreaux de pavement découverts à l'abbaye de Morimond (Haute-Marne): étude typologique, technique et archéométrique. Revue Archéol. l'Est 2013, 62, 343-366.

15. Leon, Y.; Ben Amara, A.; Conte, P. Carreaux de pavement glaçurés du château du Haut Châlucet (Haute-Vienne, XIII-XIV s.)-Inventaire et techniques de fabrication. In Proceedings of the Actes du 4ème Congrès International d'Archéologie Médiévale et Moderne, Paris, France, 3-8 September 2007; pp. 131-152.

16. De Bonis, A.; Cultrone, G.; Grifa, C.; Langella, A.; Leone, A.P.; Mercurio, M.; Morra, V. Different shades of red: The complexity of mineralogical and physico-chemical factors influencing the colour of ceramics. Ceram. Int. 2017, 43, 8065-8074. [CrossRef]

17. Jordanova, N.; Jordanova, D.; Barrón, V.; Lesigyarski, D.; Kostadinova, M. Rock-magnetic and color characteristics of archaeological samples from burnt clay from destructions and ceramics in relation to their firing temperature. Archaeol. Anthropol. Sci. 2019, 11, 3595-3612. [CrossRef]

18. Crupi, V.; D'Amico, S.; Denaro, L.; Donato, P.; Majolino, D.; Paladini, G.; Persico, R.; Saccone, M.; Sansotta, C.; Spagnolo, G.V.; et al. Mobile spectroscopy in archaeometry: Some case study. J. Spectros. 2018, 2018, 8295291. [CrossRef]

19. Ricca, M.; Paladini, G.; Rovella, N.; Ruffolo, S.A.; Randazzo, L.; Crupi, V.; Fazio, B.; Majolino, D.; Venuti, V.; Galli, G.; et al. Archaeometric characterisation of decorated pottery from the archaeological site of Villa dei Quintili (Rome, Italy): Preliminary study. Geosciences 2019, 9, 172. [CrossRef]

20. Daghmehchi, M.; Rathossi, B.; Omrani, H.; Emami, M.; Rahbar, M. Mineralogical and thermal analyses of the Hellenistic ceramics from Laodicea Temple, Iran. Appl. Clay Sci. 2018, 162, 146-154. [CrossRef]

21. Medeghini, L.; Mignardi, S.; De Vito, C.; Conte, A.M. Evaluation of a FTIR data pretreatment method for principal component analysis applied to archaeological ceramics. Microchem. J. 2016, 125, 224-229. [CrossRef]

22. Battcher, M.E.; Gehlken, P.L.; Steele, D.F. Characterization of inorganic and biogenic magnesian calcites by Fourier Transform infrared spectroscopy. Solid State Ion. 1997, 101, 1379-1385. [CrossRef]

23. Crupi, V.; La Russa, M.F.; Venuti, V.; Ruffolo, S.; Ricca, M.; Paladini, G.; Albini, R.; Macchia, A.; Denaro, L.; Birarda, G.; et al. A combined SR-based Raman and InfraRed investigation of pigmenting matter used in wall paintings: The San Gennaro and San Gaudioso Catacombs (Naples, Italy) case. Eur. Phys. J. Plus 2018, 133, 369. [CrossRef]

24. Măruţoiu, C.; Bratu, I.; Ţiplic, M.I.; Măruţoiu, V.C.; Nemeş, O.F.; Neamţu, C.; Hernanz, A. FTIR analysis and 3D restoration of Transylvanian popular pottery from the XVI-XVIII centuries. J. Archaeol. Sci. Rep. 2018, 19, 148-154. [CrossRef]

25. Torrent, J.; Schwertmann, U.; Fechter, H.; Alferez, F. Quantitative relationships between soil color and hematite content. Soil Sci. 1983, 136, 354-358. [CrossRef]

26. Torrent, J.; Barrón, V. The visible diffuse reflectance spectrum in relation to the color and crystal properties of hematite. Clays Clay Min. 2003, 51, 309-317. [CrossRef] 
27. Backes, C.J.; Cheetham, J.D.; Neff, H. The color of influence: A provenance study of hematie-based paints on early olmec carved pottery. Cambridge Univ. Press. 2012, 23, 70-92. [CrossRef]

28. Pye, K.; Blott, S.J. Particle size analysis of sediments, soils and related particulate materials for forensic purposes using laser granulometry. Forens. Sci. Int. 2004, 144, 19-27. [CrossRef] [PubMed]

29. Nagy, S.; Kuzmann, E.; Weiszburg, T.; Gyökeres-Tóth, M.; Riedel, M. Oxide transformation during preparation of black pottery in Hungary. J. Radioanal. Nucl. Chem. 2000, 246, 91-96. [CrossRef]

30. Yin, M.; Chen, Z.; Deegan, B.; O’Brien, S. Wüstite nanocrystals: Synthesis, structure and superlattice formation. J. Mater. Res. 2007, 22, 1987-1995. [CrossRef]

31. Maritana, L.; Nodarib, L.; Olivieric, L.M.; Vidale, M. Shades of black: Production technology of the black slip ware from Barikot, north-western Pakistan. J. Cult. Herit. 2020, 43, 342-355. [CrossRef]

32. Benna, P.; Tribaudino, M.; Bruno, E. The structure of ordered and disordered lead feldspar $\left(\mathrm{PbAl}_{2} \mathrm{Si}_{2} \mathrm{O}_{8}\right) . A m$. Min. 1996, 81, 1337-1343. [CrossRef]

33. Del Valle, J. Memoria de la hoja 141 (Pamplona). Mapa Geológico de España, E.1:50.000 (MAGNA), 1st ed.; IGME: Madrid, Spain, 1974; p. 26.

34. Pérez-Monserrat, E.M.; Fort, R.; López-Arce, P.; Álvarez de Buergo, M.; Varas-Muriel, M.J. Contribution of analytical techniques to determine the technologies used in the ceramic materials from the Former Workers Hospital of Maudes, Madrid (Spain). J. Eur. Ceram. Soc. 2013, 33, 479-491. [CrossRef]

35. Senvaitiene, J.; Smirnova, J.; Beganskiene, A.; Kareiva, A. XRD and FTIR characterisation of lead oxide-based pigments and glazes. Acta Chim. Sloven. 2007, 54, 185-193.

36. Schabbach, L.M.; Andreola, F.; Lancellotti, I.; Barbieri, L. Minimization of Pb content in a ceramic glaze by reformulation the composition with secondary raw materials. Ceram. Int. 2011, 37, 1367-1375. [CrossRef]

37. Thibodeau, A.M.; Habicht-Mauche, J.A.; Huntley, D.L.; Chesley, J.T.; Ruiz, J. High precision isotopic analyses of lead ores from New Mexico by MC-ICP-MS: Implications for tracing the production and exchange of Pueblo IV glaze-decorated pottery. J. Archaeol. Sci. 2013, 40, 3067-3075. [CrossRef]

38. Di Febo, R.; Molera, J.; Pradell, T.; Melgarejo, J.C.; Madrenas, J.; Vallcorba, O. The production of a lead glaze with galena: Thermal transformations in the PbS-SiO 2 system. J. Am. Ceram. Soc. 2017, 101, 2119-2129. [CrossRef]

39. Tite, M.S.; Freestone, I.; Mason, R.; Molera, J.; Vendrell-Saz, M.; Wood, N. Lead glazes in antiquity-Methods of production and reasons for use. Archaeometry 2007, 40, 241-260. [CrossRef]

40. Hurst, D.; Freestone, I. Lead Glazing Technique from a Medieval Klin Site at Hanley Swan, Worcestershire. Mediev. Ceram. 1996, 20, 13-18.

41. Molera, J.; Pradell, T.; Salvadó, N.; Vendrell-Saz, M. Interactions between Clay Bodies and Lead Glazes. J. Am. Ceram. Soc. 2001, 84, 1120-1128. [CrossRef]

42. Ben Amara, A.; Schvoerer, M. Interactions between lead glazes and bodies: Research on the mode of application of the glazing mixture. Institución Fernando el Católico. In Proceedings of the 34th International Symposium on Archaeometry, Zaragoza, Spain, 3-7 May 2006; pp. 399-404.

43. Yonga, B.; Yanga, T.; Yanga, B.; Xu, B.Q.; Liua, D.C.; Zhang, W. Preparation of lead oxide from the recycled lead carbonate by vacuum T decomposition technology. Vacuum 2019, 167, 445-451. [CrossRef] 